\title{
Tissue-specific Expression of the Gene Coding for Human Clara Cell 10-kD Protein, a Phospholipase $\mathbf{A}_{2}$-inhibitory Protein
}

\author{
Alessandro Peri, Eleonora Cordella-Miele, Lucio Miele, and Anil B. Mukherjee \\ Section on Developmental Genetics, Human Genetics Branch, National Institute of Child Health and Human Development, \\ National Institutes of Health, Bethesda, Maryland 20892
}

\begin{abstract}
Clara cell 10-kD protein (cc10kD), a secretory phospholipase $A_{2}$ inhibitor, is suggested to be the human counterpart of rabbit uteroglobin (UG). Because cc10kD is expressed constitutively at a very high level in the human respiratory epithelium, the $5^{\prime}$ region of its gene may be useful in achieving organ-specific expression of recombinant DNA in gene therapy of diseases such as cystic fibrosis. However, it is important to establish the tissue-specific expression of this gene before designing gene transfer experiments. Since the UG gene in the rabbit is expressed in many other organs besides the lung and the endometrium, we investigated the organ and tissue specificity of human cc10kD gene expression using polymerase chain reaction, nucleotide sequence analysis, immunofluorescence, and Northern blotting. Our results indicate that, in addition to the lung, cc10kD is expressed in several nonrespiratory organs, with a distribution pattern very similar, if not identical, to that of UG in the rabbit. These results underscore the necessity for more detailed analyses of the $5^{\prime}$ region of the human cc10kD gene before its usefulness in gene therapy could be fully assessed. These data also suggest that cc10kD and UG may have similar physiological function(s). (J. Clin. Invest. 1993. 92:20992109.) Key words: Clara cell $10-\mathrm{kD}$ protein • uteroglobin • mRNA • gene expression • tissue distribution
\end{abstract}

\section{Introduction}

One of the major secretory products of human pulmonary Clara cells is the $10-\mathrm{kD}$ protein $(\mathrm{ccl} 10 \mathrm{kD})^{1}(1)$, also known as $17-\mathrm{kD}$ protein (2). This protein is a homodimer consisting of 70 amino acid subunits connected by two disulfide bonds (3). The name cc10kD derives from the apparent molecular mass of this protein in nonreducing SDS-PAGE (1). The cDNA (3) as well as the gene (4) for this protein have been cloned and characterized. The exact physiological role of cc $10 \mathrm{kD}$ is yet to be clarified. However, several biological properties, including its phospholipase $\mathrm{A}_{2}$ ( $\mathrm{PLA}_{2}$ )-inhibitory activity (5) and its ability to bind methylsulfonyl polychlorinated biphenyls (6), have

Address correspondence to Dr. Anil B. Mukherjee, Building 10, Room 9S242, National Institutes of Health, Bethesda, MD 20892.

Received for publication 24 March 1993 and in revised form 11 June 1993

1. Abbreviations used in this paper: $\mathrm{cc} 10 \mathrm{kD}$, Clara cell $10-\mathrm{kD}$ protein; DEPC, diethyl pyrocarbonate; GAPDH, glyceraldehyde 3-phosphate dehydrogenase; hUG-L2 and -R, human uteroglobin left 2 and right; hULP-L and -R, human uteroglobin-like primer left and right; PLA $A_{2}$, phospholipase $\mathrm{A}_{2} ; T_{\mathrm{m}}$, melting temperature; UG, uteroglobin.

The Journal of Clinical Investigation, Inc.

Volume 92, November 1993, 2099-2109 been established. The amino acid sequence of $\mathrm{cc} 10 \mathrm{kD}$ deduced from its cDNA sequence bears a striking similarity to that of rabbit uteroglobin (UG) (3).

Blastokinin (7) or UG (8) is a steroid-dependent secretory protein with a low molecular mass $(15.8 \mathrm{kD})$. This protein was first discovered in the rabbit uterine fluid during early pregnancy (for a review see reference 9). Subsequently, in a number of independent immunocytochemistry studies, UG was found to be expressed in the epithelial cells of several extrauterine tissues (10-16).

Some of the biological properties of UG, such as masking the antigenicity of blastomeres (17-19) and epididymal spermatozoa (20), inhibition of monocyte and neutrophil chemotaxis and phagocytosis in vitro (21-23), and inhibition of ADP- and thrombin-induced (but not of arachidonic acid-induced ) platelet aggregation (24), may be due, at least in part, to the potent inhibitory effect of this protein on $\mathrm{PLA}_{2}$ activity (25). A nonapeptide derived from the amino acid sequence of $\alpha$-helix-3 of UG monomer (residues $39-47$ ) possesses all the biological properties of the intact protein and has been identified as an active site of $U G$ responsible for its $P_{2} A_{2}$-inhibitory and antiinflammatory activities (26-37).

In spite of many structural and functional similarities between $\mathrm{UG}$ and cc $10 \mathrm{kD}$ protein, there are some controversies as to whether these two proteins are counterparts of each other ( 3 , 5). We reasoned that, if cclokD is the human counterpart of rabbit UG, its tissue distribution should be very similar or identical to that of UG. Thus, we investigated whether the expression of cc10kD in human organs follows the same pattern of tissue-specific expression as has been established for rabbit UG.

Because of the constitutive high level of expression of cclokD gene in the lung, the use of the 5 ' region of this gene is potentially useful in gene therapy for obtaining organ-specific expression of a wild-type gene to correct a genetic mutation or deficiency in the respiratory epithelia. Thus, it is important to delineate the organ- and tissue-specific expression of cc10kD gene before its $5^{\prime}$ region can be used for such experiments. We have investigated the expression of this gene in various human organs and tissues by PCR, Northern blotting, and immunofluorescence. Our data indicate that, in addition to the lung, human cc10kD gene is expressed in several nonrespiratory organs, as has been previously reported for rabbit UG. These data, taken together with the structural and functional similarities of these two proteins, provide strong supporting evidence that human cclokD is the counterpart of rabbit UG and that cc10kD is not expressed exclusively in the pulmonary Clara cells. These results underscore the necessity for further characterization of the $5^{\prime}$ region of this gene in order to determine whether specific genetic elements facilitating the expression of exogeneous genes, specifically in the respiratory epithelia, can be identified. Moreover, the almost identical tissue-specific expression of cc10kD and UG genes may suggest that these two proteins have very similar physiological roles. 


\section{Methods}

\section{cDNAs}

Human cDNAs from the following organs and tissues were purchased from Clontech Laboratories Inc. (Palo Alto, CA ): brain, pituitary, thymus, thyroid, trachea, lung, mammary gland, heart, aorta, endothelial cells, stomach, small intestine, pancreas, spleen, liver, kidney, adrenal, ovary, uterus, placenta, prostate, testis, and leukocytes.

\section{$\operatorname{Poly}(A)^{+}$RNAs}

Poly $(\mathrm{A})^{+}$RNAs from human mammary gland, prostate, thyroid, trachea, and human multiple tissue Northern blot were also purchased from Clontech Laboratories Inc.

\section{Oligonucleotide primers and probe:}

Purified oligonucleotide primers for amplification of cc10kD cDNA were obtained from Bio-Synthesis Inc. (Lewisville, TX). Two different sets of sense and antisense primers were synthesized. These primers were designed so that they would allow the PCR amplification of the entire coding region of cclokD gene. The first set consisted of human uteroglobin-like primer right (hULP-R) (5'-TACACAGTGAGCTTTGGGC-3'; melting temperature $\left.\left[T_{\mathrm{m}}\right]=67^{\circ} \mathrm{C}\right)$, which corresponded to nucleotide residues 278-260 and human uteroglobin-like primer left (hULP-L) (5'-ATGAAACTCGCTGTCACCC-3'; $T_{\mathrm{m}}=68^{\circ} \mathrm{C}$ ), corresponding to nucleotide residues $8-26$ of $c c 10 \mathrm{kD}$ cDNA. The second set included human uteroglobin right (hUG-R) (5'-GAAGAGAGCAAGGCTGGTGG-3'; $T_{\mathrm{m}}=73^{\circ} \mathrm{C}$, residues $367-348$ ) and human uteroglobin left 2 (hUG-L2) (5'-CTCCACCATGAAACTCGCTG-3'; $T_{\mathrm{m}}=$ $72^{\circ} \mathrm{C}$, residues $1-20$ of $\mathrm{cc} 10 \mathrm{kD} \mathrm{cDNA}$ ). The sequence of the oligonucleotide probe (hUG-P) corresponded to nucleotides 192-211 of ccl0kD cDNA (5'-TGAAGAAGCTGGTGGACACC-3'; $T_{\mathrm{m}}=$ $71^{\circ} \mathrm{C}$ ). hUG-P was labeled at the $3^{\prime}$ end with digoxigenin-11-ddUTP using the Genius 5 kit (Boehringer Mannheim Biochemicals, Indianapolis, IN) according to manufacturer's instructions. The $T_{\mathrm{m}} \mathrm{s}$ of primers and probe were calculated by means of the program PRIMER DESIGNER version 1.0 (Scientific \& Educational Software, State Line, PA).

Oligonucleotide primers for amplification of glyceraldehyde 3-phosphate dehydrogenase (GAPDH) cDNA, used as control, were also purchased from Bio-Synthesis Inc. The sequence of the sense primer (GAPDH-L) was 5'-CCATGGAGAAGGCTGGGG-3' $\left(T_{\mathrm{m}}=74^{\circ} \mathrm{C}\right.$, position 388-405 of GAPDH cDNA) and that of the antisense primer (GAPDH-R) was 5'-CAAAGTTGTCATGGATGACC-3' $\left(T_{\mathrm{m}}\right.$ $=66^{\circ} \mathrm{C}$, position $\left.582-563\right)$. These primers have been previously described by Dveksler et al. (38).

\section{Other materials}

The Gene Amp PCR reagent kit with Ampli TAQ DNA polymerase was purchased from Perkin Elmer Cetus (Norwalk, CT). Digoxigenin11-dUTP, Lumi-Phos 530, anti-digoxigenin-alkaline phosphataseconjugated antibody, blocking reagent, and goat anti-rabbit antibody labeled with FITC were from Boehringer-Mannheim Biochemicals. Diethyl pyrocarbonate (DEPC)-treated ultra pure DNAase-RNAase free water and $20 \times$ standard saline citrate (SSC; $3 \mathrm{M} \mathrm{NaCl}, 0.3 \mathrm{M}$ trisodium citrate, $\mathrm{pH} 7$ ) were obtained from 5 Prime-3 Prime, Inc. (Boulder, CO). DEPC, EDTA, xylene cyanol FF, and mineral oil were from Sigma Chemical Co. (St. Louis, MO). Hybridization denaturing solution (1.5 M NaCl, $0.5 \mathrm{M} \mathrm{NaOH}$ ), hybridization neutralization solution ( $1.5 \mathrm{M} \mathrm{NaCl}, 1.0 \mathrm{M}$ Tris), and $1 \times \mathrm{TE}$ buffer ( $10 \mathrm{mM}$ Tris, 1 mM EDTA) were purchased from Digene Diagnostic Inc. (Silver Spring, MD). NuSieve and SeaPlaque agarose were from FMC Corp. BioProducts (Rockland, ME). Ultra pure agarose, ethidium bromide, and RNA ladder 0.16-1.77 $\mathrm{kb}$ were purchased from Gibco BRL (Gaithersburg, MD). Nytran membranes were obtained from Schleicher \& Schuell Inc. (Keene, NH) and Magna Charge nylon transfer membranes from Micron Separations Inc. (Westboro, MA). $\mathrm{N}$-Lauroylsarcosine ( $\mathrm{Na}$ salt) was purchased from ICN Biochemicals (Cleveland, OH). SDS, acrylamide, and bromophenol blue were from Bio-Rad Laboratories(Richmond, CA). Magic PCR Preps DNA purifi- cation system and "fmol" DNA sequencing system were obtained from Promega Biotec (Madison, WI). $\alpha-\left[{ }^{35} \mathrm{~S}\right] \mathrm{dATP}$ was purchased from Amersham Corp. (Arlington Heights, IL). Acetic acid was from Baker Chemical Co. (Phillipsburg, NJ), PBS from Biofluids (Rockville, MD), and maleic acid from Eastman Laboratory and Specialty Chemicals (Rochester, NY). Sodium acetate, glycerol, sodium chloride, sodium hydroxide, and xylene were from Mallinckrodt Inc. (Paris, KY). 3-Morpholinopropanesulfonic acid, formaldehyde, and formamide were obtained from Fluka Chemical Corp. (Ronkonkoma, NY).

\section{PCR amplification}

PCR was performed using a DNA thermal cycler (model 480; Perkin Elmer Cetus, Norwalk, CT) and the Gene Amp PCR reagent kit with Ampli TAQ DNA polymerase. The reaction mixture $(100 \mu \mathrm{l})$ contained: $4 \mathrm{mM} \mathrm{MgCl}{ }_{2}, 1 \times$ PCR buffer, $200 \mu \mathrm{M}$ dATP, $200 \mu \mathrm{M}$ dCTP, $200 \mu \mathrm{M}$ dGTP, $200 \mu \mathrm{M}$ dTTP (or $193 \mu \mathrm{M}$ dTTP $+7 \mu \mathrm{M}$ digoxigenin11-dUTP), 2.5 U Ampli TAQ polymerase, $300 \mathrm{nM}$ sense primer, and $300 \mathrm{nM}$ antisense primer. The reagents were diluted as needed with DEPC-treated ultra pure water. The human cDNAs ( $2 \mathrm{ng} /$ reaction), used as templates, were heated for $10 \mathrm{~min}$ at $95^{\circ} \mathrm{C}$ and then kept on ice before addition to the reaction mixture. $50 \mu \mathrm{l}$ of mineral oil was added to each tube to avoid evaporation during PCR. Each sample was further heated for $2 \mathrm{~min}$ at $95^{\circ} \mathrm{C}$ in the thermal cycler. Each amplification cycle included a denaturation step $\left(1 \mathrm{~min}\right.$ at $\left.95^{\circ} \mathrm{C}\right)$ and an annealingextension step $\left(1.5 \mathrm{~min}\right.$ at $63^{\circ} \mathrm{C}$ using hULP-R/hULP-L or $1.5 \mathrm{~min}$ at $68^{\circ} \mathrm{C}$ using hUG-R/hUG-L2 as primers). The cDNAs were amplified for a total of 30 cycles. A final annealing-extension period ( $10 \mathrm{~min}$ at $63^{\circ} \mathrm{C}$ with hULP-R/L or $68^{\circ} \mathrm{C}$ with hUG-R/L2) followed the last cycle.

In PCR experiments with GAPDH primers, the reaction mixture was identical to that described above. The concentration of the primers was also the same. After denaturation for $2 \mathrm{~min}$ at $95^{\circ} \mathrm{C}$ the cDNAs were subjected to 30 amplification cycles, which included denaturation for $1 \mathrm{~min}$ at $95^{\circ} \mathrm{C}$, annealing for $1 \mathrm{~min}$ at $61^{\circ} \mathrm{C}$, and extension for $1 \mathrm{~min}$ at $72^{\circ} \mathrm{C}$. After the last cycle, the amplification was continued for an additional $10 \mathrm{~min}$ at $72^{\circ} \mathrm{C}$. We have determined that, with 30 cycles of amplification, the level of GAPDH PCR product does not reach a plateau under these experimental conditions (not shown). To prevent contaminations, different sets of pipettes were used to dispense the reagents and the cDNAs into the tubes. Yet another set of pipettes was used for the products. Furthermore, the cDNAs and products were handled in separate areas. All pipettes and tubes were irradiated for $1 \mathrm{~h}$ with short-wave ultraviolet (UV) light before use. Aerosol-resistant tips were used in all procedures.

\section{Detection and characterization of PCR products}

Detection of PCR products containing digoxigenin-11-dUTP. $10 \mu \mathrm{l}$ of PCR product was electrophoresed on $2 \%$ NuSieve, $1 \%$ BRL Ultra Pure agarose gels. After alkaline denaturation for $45 \mathrm{~min}$, the gels were neutralized for $30 \mathrm{~min}$. After $30 \mathrm{~min}$ the neutralization solution was replaced with fresh solution and the gels were incubated for an additional $15 \mathrm{~min}$. DNA bands were transferred overnight onto nylon membranes (Nytran; Schleicher \& Schuell Inc.) by conventional capillary blotting. PCR products were then cross-linked to the membranes by UV irradiation for $3 \mathrm{~min}$ in a Stratalinker $1800 \mathrm{UV}$ (Stratagene, La Jolla, CA). Amplified DNA bands were detected using an immunochemiluminescent method. The detection procedure was performed as recommended by the manufacturer (Boehringer-Mannheim Biochemicals). Briefly, membranes were incubated in the presence of an antidigoxigenin alkaline phosphatase-conjugated antibody and then passed through Lumi-Phos 530. Chemilumigrams were obtained by exposing the filters to $x$-ray films (Kodak X-OMAT-AR) and the DNA bands were visualized. To compare qualitatively the results obtained from amplification of cDNAs from different organs, the time of exposure to $\mathrm{x}$-ray films was kept constant ( $1 \mathrm{~min}$ of exposure, $10 \mathrm{~min}$ after the application of Lumi-Phos 530 for cc10kD, and $1 \mathrm{~min}$ of exposure, immediately after the application of Lumi-Phos 530 for GAPDH). The bands were scanned with a laser densitometer (UltraScan 2202; Pharmacia LKB Biotechnology, Piscataway, NJ). 
Hybridization of PCR products with digoxigenin-11-ddUTP-labeled $h U G-P$. In these experiments, PCR amplification was performed without digoxigenin-11-dUTP. After gel electrophoresis and transfer to nylon membranes, PCR products were hybridized with a digoxigeninlabeled probe (hUG-P). After cross-linking the DNAs to the membranes, blots were incubated for $2 \mathrm{~min}$ in $5 \times \mathrm{SSC}$ and then were further incubated for $1.5 \mathrm{~h}$ at $66^{\circ} \mathrm{C}$ in prehybridization solution ( $5 \times \mathrm{SSC}, 0.1 \%$ $\mathrm{N}$-lauroylsarcosine $\mathrm{Na}$ salt, $0.02 \% \mathrm{SDS}, 1 \%$ Boehringer blocking reagent). After this incubation the amplified cDNAs were hybridized with $5 \mathrm{nM}$ digoxigenin-labeled probe (hUG-P) for $4 \mathrm{~h}$ at $66^{\circ} \mathrm{C}$. Before mixing with the prehybridization solution, the probe was heated for 10 min at $95^{\circ} \mathrm{C}$ and rapidly chilled on ice. Posthybridization washes were performed as follows: twice for $5 \mathrm{~min}$ at $37^{\circ} \mathrm{C}$ in $2 \times \mathrm{SSC}, 0.1 \% \mathrm{SDS}$; once for $5 \mathrm{~min}$ at $66^{\circ} \mathrm{C}$ in $0.1 \times \mathrm{SSC}, 0.1 \%$ SDS. Hybridized probe was then detected as described above. $45 \mathrm{~min}$ after the application of LumiPhos 530, the membranes were exposed to the films for $3 \mathrm{~min}$.

\section{Nucleotide sequence analysis of PCR products}

Partial nucleotide sequencing of PCR products (hULP-R/hULP-L as primers) from human prostate and thymus CDNA was performed as follows: the PCR products were precipitated at $-20^{\circ} \mathrm{C}$ overnight in 300 $\mathrm{mM}$ sodium acetate, $70 \%$ ethanol, washed three times for $5 \mathrm{~min}$ in $70 \%$ ethanol, dried under vacuum, and resuspended in $10 \mu \mathrm{l}$ of $1 \times \mathrm{TE}$ buffer. DNAs were loaded onto a $2 \%$ NuSieve, $1 \%$ SeaPlaque low-melting-temperature agarose gel. Specific bands were excised and the agarose slices were kept for $10 \mathrm{~min}$ at $70^{\circ} \mathrm{C}$. Purification from agarose slices was performed by the Magic PCR Preps DNA Purification System (Promega Biotec), as recommended by the manufacturer. Purified DNAs were used as templates in the sequencing reactions, which were performed using the "fmol" DNA Sequencing System (Promega Biotec) according to the manufacturer's instructions. After this, $3 \mu \mathrm{l}$ of each reaction mixture was loaded on an $8 \%$ acrylamide sequencing gel (0.2 $\mathrm{mm}$ thick). Gel electrophoresis was performed using the Macrophor sequencing system (Pharmacia LKB Biotechnology) at $55^{\circ} \mathrm{C}$. The gel was then soaked for $30 \mathrm{~min}$ in $10 \%$ acetic acid, dried overnight, and exposed to $\mathrm{x}$-ray film (Kodak X-OMAT-AR) for $\mathbf{4 8 ~ h}$.

\section{Northern blotting}

$2.5 \mu \mathrm{g}$ of human mammary gland, prostate, thyroid, and trachea poly (A) ${ }^{+}$RNA and $4 \mu \mathrm{g}$ of RNA ladder $0.16-1.7 \mathrm{~kb}$ were electrophoresed through a 2\% BRL Ultra Pure agarose gel containing $2.2 \mathrm{M}$ formaldehyde. At the end of the run the lane containing the markers was cut, stained with ethidium bromide, and photographed. The remaining portion of the gel was rinsed in DEPC-treated ultra pure water and then soaked for $45 \mathrm{~min}$ in $20 \times$ SSC. RNAs were transferred overnight onto charged nylon membranes (Micron Separations Inc.) by conventional capillary blotting. The RNAs were cross-linked to the membrane by UV irradiation $\left(0.12 \mathrm{~J} / \mathrm{cm}^{2}\right)$ in a UV Stratalinker-1800 (Stratagene). Hybridization and chemiluminescent detection of the RNAs were performed following the protocol for detection of digoxigenin-labeled nucleic acids (Boehringer-Mannheim Biochemicals). The probe for cc10kD mRNA was derived from PCR amplification of human lung cc10kD cDNA using hULP-R/L as primers; the probe used for detection of GAPDH mRNA was a 195-bp PCR product obtained from human ovary cDNA using GAPDH-R/L primers. In both cases probes were labeled during amplification by including $7 \mu \mathrm{M}$ digoxigenin-11dUTP in the reaction mixture. PCR products were precipitated and electrophoresed through a $2 \%$ NuSieve, $1 \%$ SeaPlaque low-melting agarose gel. Specific bands were excised and purified from agarose using the Magic PCR Preps DNA purification system (Promega). For this blot, the probes were used simultaneously, each at a concentration of $20 \mathrm{ng} / \mathrm{ml}$ of prehybridization solution $(5 \times \mathrm{SSC}, 50 \%$ formamide, $0.02 \%$ SDS, $0.1 \% N$-lauroylsarcosine, $2 \%$ Boehringer blocking reagent, $20 \mathrm{mM}$ sodium maleate, $\mathrm{pH} 7.5$ ), and hybridization was carried out for $18 \mathrm{~h}$ at $42^{\circ} \mathrm{C}$. Posthybridization washes were performed as follows: twice for $5 \mathrm{~min}$ at room temperature in $2 \times \mathrm{SSC}, 0.1 \%$ SDS; twice for 15 min at $65^{\circ} \mathrm{C}$ in $0.5 \times \mathrm{SSC}, 0.1 \%$ SDS. Hybridization and detection of poly $(\mathrm{A})^{+}$RNAs from heart, brain, placenta, lung, liver, skeletal mus- cle, kidney, and pancreas ( $2 \mu \mathrm{g}$ each $)$ contained in the human multiple tissue Northern blot (Clontech) were performed using the same procedure. This blot was first used for cc10kD mRNA detection, stripped in $60 \%$ formamide, $50 \mathrm{mM}$ Tris- $\mathrm{HCl}, 1 \% \mathrm{SDS}, \mathrm{pH} 8$, for $1 \mathrm{~h}$ at $75^{\circ} \mathrm{C}$ and then rehybridized for GAPDH mRNA detection. Chemilumigrams of the bands were obtained by exposing the membranes to $x$-ray films (Kodak X-OMAT-AR) for $30 \mathrm{~min}, 7 \mathrm{~h}$ after the application of LumiPhos 530. The bands were scanned with a laser densitometer (Ultroscan 2202; Pharmacia LKB Biotechnology).

\section{Immunofluorescence}

Autopsy specimens from human prostate, lung, thymus, and pituitary were fixed in $4 \%$ paraformaldehyde; and paraffin-embedded sections were placed on glass slides. These tissue sections were used for immunofluorescence according to a previously described method (18). Briefly, paraffin was removed with xylene and the slides containing the tissue sections were passed through a series of decreasing concentrations of ethanol (100-70\%) and then rinsed in PBS ( $\mathrm{pH} 7.4$ ). Excess PBS was shaken off the slides and $50 \mu$ l of diluted (1:5) rabbit anti-human cc10kD antibody was layered over the sections. This antibody was produced in a rabbit by injecting a synthetic oligopeptide corresponding to amino acid residues $37-55$ of human $\mathrm{cc} 10 \mathrm{kD}$ protein as antigen. The slides were incubated in a humidified chamber for $1 \mathrm{~h}$ at room temperature. As control, some of the slides were stained with rabbit anti-human cc $10 \mathrm{kD}$ antibody, which had been preadsorbed with an excess of pure recombinant cc10kD protein (38a). Also, in some control slides the first antibody was omitted. The slides were then washed in PBS for 30 min with constant agitation. Goat FITC-labeled anti-rabbit antibody (Boehringer Mannheim Biochemicals) $(50 \mu \mathrm{l})$ at 1:10 dilution was added to each tissue section and the slides were incubated in a humidified chamber for $\mathbf{4 5} \mathrm{min}$ at room temperature. The sections were then washed three times for 15 min with PBS with constant agitation and rinsed with $50 \mathrm{mM}$ sodium bicarbonate buffer ( $\mathrm{pH} 9.5$ ). Excess buffer was shaken off and the slides were mounted in $50 \%$ glycerol-sodium bicarbonate buffer, coverslipped, sealed with nail polish, and examined with a Zeiss photomicroscope under epifluorescence. Photomicrographs $(\times 630)$ were taken using Kodak Tri-X pan 400 film.

\section{Results}

Detection of cc10kD-specific cDNA in human organs. We have detected cc10kD-specific transcriptional signal in $18 / 23 \mathrm{hu}-$ man organs investigated in the present study. Although precise levels of cc10kD gene transcript cannot be assessed directly from our data, qualitatively the tissues could be categorized into three distinct groups on the basis of the amount of specific PCR product. This was confirmed by densitometric analysis (Table I). The first group (Fig. 1), which included cDNAs from lung, trachea, prostate, thyroid, mammary gland, and pituitary, yielded very high levels of specific PCR product. PCR-amplified products from these tissues were unambiguously detected on ethidium bromide-stained gels (Fig. $1 A$ ), using two different sets of primers. Fig. $1 B$ shows the results of immunochemiluminescent detection (Lumi-Phos 530; Boehringer-Mannheim Biochemicals) of the same bands shown in Fig. $1 \mathrm{~A}$. The tissue-specific signals obtained for GAPDH transcription (Fig. $1 C$ ) are virtually identical, indicating that the quality of cDNAs used for our studies was excellent, as equal amounts of these cDNAs generated comparable amounts of GAPDH product. The identity of cc $10 \mathrm{kD}$ amplification products was confirmed by hybridization with hUG-P, which was derived from an entirely different region of the cc10kD cDNA from the primers. The results are shown in Fig. $1 D$ and demon- 
Table I. Densitometric Analysis of PCR Product Bands in Direct Chemilumigrams

\begin{tabular}{llll}
\hline \multicolumn{1}{c}{ Tissue } & $\begin{array}{c}\text { Area of } \\
\text { ccl0kD } \\
\text { band }\end{array}$ & $\begin{array}{c}\text { Area of } \\
\text { GAPDH } \\
\text { band }\end{array}$ & $\begin{array}{c}\text { Ratio of } \\
\text { ccl0kD } \\
\text { to GAPDH }\end{array}$ \\
\hline Lung & 2.31 & 0.93 & 2.48 \\
Trachea & 1.98 & 1.14 & 1.74 \\
Prostate & 2.51 & 1.19 & 2.11 \\
Thyroid & 1.68 & 1.09 & 1.54 \\
Mammary gland & 2.07 & 1.18 & 1.75 \\
Pituitary & 1.79 & 0.90 & 1.99 \\
Stomach & 1.20 & 1.12 & 1.07 \\
Ovary & 1.07 & 1.23 & 0.87 \\
Testis & 1.05 & 1.15 & 0.91 \\
Spleen & 1.16 & 0.92 & 1.26 \\
Adrenal gland & 1.06 & 1.05 & 1.01 \\
Aorta & 1.22 & 0.96 & 1.27 \\
Pancreas & 0.87 & 0.25 & 3.48 \\
Liver & 0.51 & 1.12 & 0.45 \\
Thymus & 0.40 & 1.21 & 0.33 \\
Small intestine & 0.06 & 1.13 & 0.05 \\
Placenta & 0.06 & 0.88 & 0.07 \\
Uterus & 0.13 & 1.05 & 0.12 \\
Brain & n.d. & 1.05 & - \\
Endothelium & n.d. & 1.03 & - \\
Heart & n.d. & 1.08 & - \\
Kidney & n.d. & 1.01 & - \\
Leukocytes & n.d. & 1.10 & - \\
\hline & & & \\
\hline
\end{tabular}

Bands obtained with hULP-R/L primers are reported for cc10kD product. The values obtained with hUG-R/L2 follow the same pattern. * Areas were calculated by means of a reporting integrator (model 3390A; Pharmacia LKB Biotechnology) and are expressed in densitometric units $\times 10^{-7}$; n.d., not detectable.

strate that specific signals were obtained from all the tissues in this group, using either hULP-R/L or hUG-R/L2 for amplification.

The second group of cDNAs includes those tissues in which a relatively lower level of cc10kD-specific product was detected. In this case DNA bands were undetectable by ethidium bromide staining, although high density bands of the expected molecular mass were observed after detection with Lumi-Phos 530 (Fig. $2 \mathrm{~A}$ ). Stomach, ovary, testis, spleen, adrenal, aorta, pancreas, liver, and thymus were included in this group. The amounts of GAPDH-specific PCR products were also nearly identical for these tissues except for the pancreas (Fig. $2 \mathrm{~B}$ ). In this DNA sample the amount of GAPDH PCR product was clearly lower than those obtained with cDNAs from other tissues. It may be noted that the pancreas is a rich source of RNAse and that undegraded preparations of mRNA are more difficult to obtain from this organ. The cc10kD PCR products from all the tissues in this group hybridized with hUG-P (Fig. 2 $C)$, confirming that these amplified products are derived from cc10kD cDNA.

A third group of cDNAs includes those that generated barely detectable or undetectable cc10kD-specific PCR products (data not shown). In spite of the good quality of the cDNAs, as ascertained by amplification with GAPDH primers, trace amounts of $\mathrm{cc} 10 \mathrm{kD}$ products were detected in only some of the tissues included in this group. PCR products obtained using hULP-R/L or hUG-R/L2 primers were detectable by direct chemilumigram in small intestine, placenta, and uterus. Only the products obtained using hULP-R/L primers could be detected by hybridization with hUG-P. Specific signals from amplification of cDNAs from endothelium, kidney, heart, brain, and leukocytes were either not detected or barely seen after much longer exposures of the chemilumigram. In all PCR experiments, a blank sample, as control, was subjected to amplification in the absence of any cDNA. As expected, no product was detected in these samples. This excluded the possibility of inadvertent contamination of PCR reagents by CDNA or PCR products.

To obtain a semiquantitative estimate of the amount of PCR product formed using equal amounts of tissue-specific cDNAs, densitometric analysis of specific bands in direct chemilumigrams representing the cc10kD- and GAPDH-specific DNAs was performed. The results, presented in Table I, further support our contention that the tissues tested can be divided into three groups. Except for the pancreas, the variation in the levels of GAPDH-specific products was very low $(1.07 \pm 0.1$ densitometric units, mean $\pm \mathrm{SD}$ ). On the other hand, the amount of cc10kD-specific products showed a much wider variation. The absolute values for $c c 10 \mathrm{kD}$ bands ranged from 1.68 to 2.51 densitometric units in the first group, from 0.4 to 1.22 in the second, and from nondetectable values to 0.13 in the third. An estimate of the amount of cc10kD-specific product formed for each sample was based on the ratio between the optical densities of the bands representing cc10kD and GAPDH PCR products, respectively. The calculated values were 1.54-2.48 in the first group; $0.33-1.27$ in the second group, with the exception of the pancreas (3.48); and not calculable (absent cclokD band) to 0.12 in the third group. The high value calculated for the pancreas suggests that the actual abundance of specific cclokD template in pancreatic cDNA may be higher than what is apparent if the absolute amount of the PCR product alone is taken into account.

Nucleotide sequence analyses of PCR products of prostateand thymus-derived $c D N A s$. To further confirm the identity of PCR products obtained from organs other than the lung, partial direct nucleotide sequence analyses of the amplified cDNAs from prostate and thymus were performed. The results are shown in Fig. 3. For the prostate, the sequence of almost the entire length of the PCR product was determined ( 230 out of 271 nucleotides), whereas for the thymus the sequence of only 85 nucleotides was obtained. This is because the amount of PCR product from the thymus was much lower than that of the prostate. However, the partial nucleotide sequences of PCR products from both tissues were identical to the published sequence of the corresponding regions of human $c c 10 \mathrm{kD}$ cDNA (25).

Northern blotting. Poly (A) ${ }^{+}$RNAs from different human tissues were tested for cc10kD mRNA by Northern analysis. GAPDH gene expression was also assessed, in order to test the integrity of the RNAs. The results are shown in Fig. 4. In Fig. 4 $A$ the bands obtained by hybridization and chemiluminescent detection of a multiple tissue Northern blot (Clontech) are shown. Among these tissues, a specific $0.6-\mathrm{kb}$ band for $\mathrm{cc} 10 \mathrm{kD}$ mRNA (arrow) was detected only in the lung. The intensity of specific GAPDH mRNA bands $(1.3 \mathrm{~kb})$ was generally similar in the tissues tested, except for the skeletal muscle and the heart, which showed a higher level of expression, and the pan- 


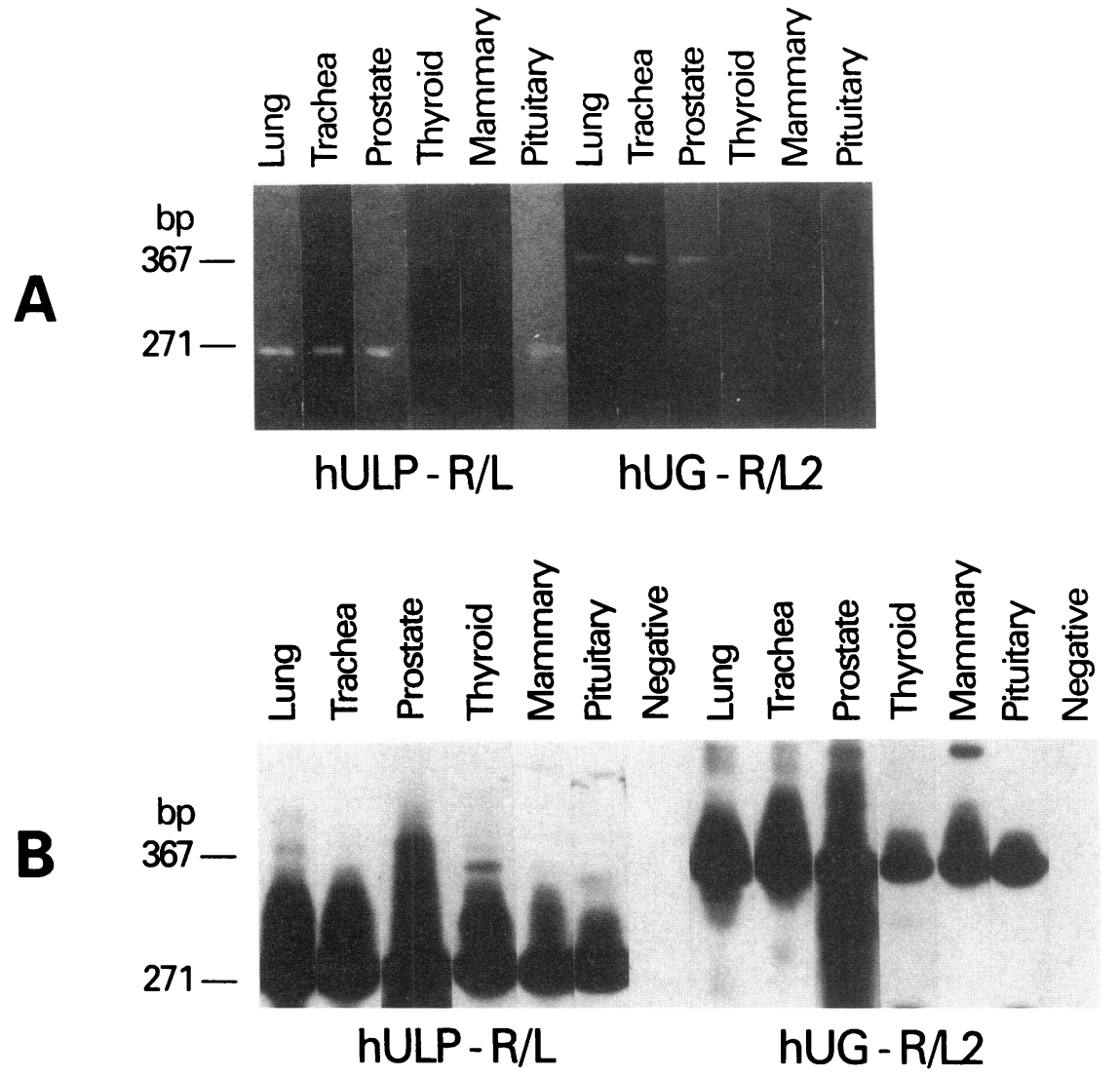

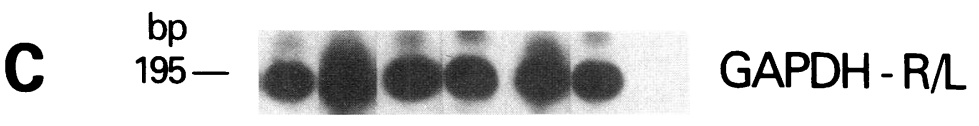

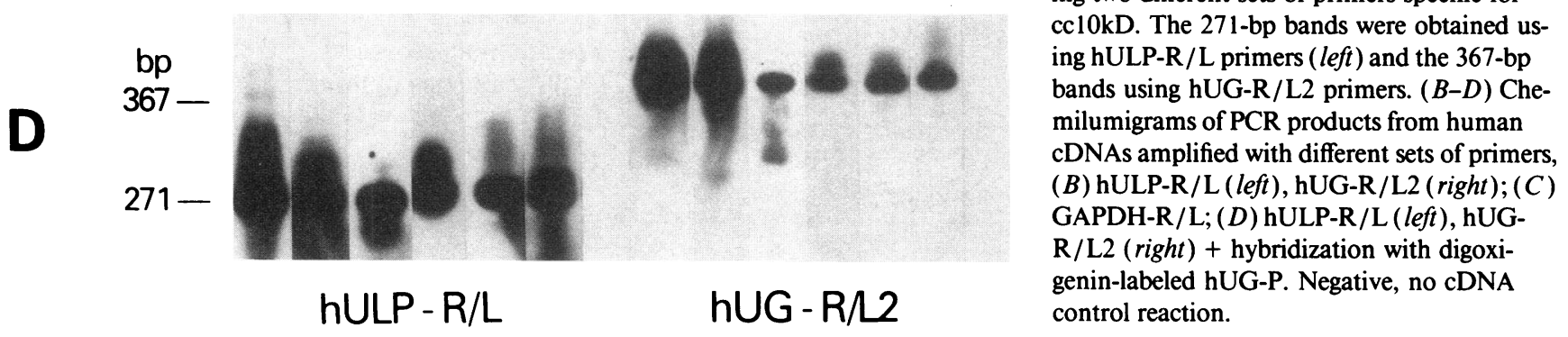

creas, in which a specific band was barely detected. This again attests to the difficulty of obtaining an undegraded preparation of mRNA from the pancreas. Fig. $4 B$ shows the results obtained by Northern analysis of poly $(A)^{+}$RNAs from human mammary gland, prostate, thyroid, and trachea. A clear $0.6-\mathrm{kb}$ band for cc10kD mRNA (bottom arrow) was observed in the samples from trachea and prostate. A very faint band was visible in the mammary gland sample and could be detected by densitometry but is not clearly discernible in a photograph. GAPDH mRNA bands ( top arrow) were almost identical in all tissues. The bands in the Northern blots were scanned with a laser densitometer and the results are reported in Table II. Only the values obtained for the blot shown in Fig. $4 \mathrm{~B}$ can be directly compared with each other because the samples were run on the same gel and the membrane was hybridized simulta- neously with cc10kD and GAPDH probes. This prevented possible artifacts due to stripping and reprobing of the membrane, which in the multiple tissue Northern blot caused a considerable decrease in sensitivity of GAPDH mRNA detection in the second hybridization. The variation in the intensity of the bands representing GAPDH mRNA in human trachea, prostate, and mammary gland was very low $(0.24 \pm 0.02$ densitometric units, mean $\pm \mathrm{SD}$ ). For these samples the ratio of cc10kD to GAPDH may give an estimate of the amount of cc10kD mRNA in different tissues. The values obtained show that cc $10 \mathrm{kD}$ mRNA in the trachea is $\sim 14$-fold more abundant than in the prostate and $\sim 24$-fold more abundant than in the mammary gland.

Immunofluorescence. Indirect immunofluorescence with an antibody to human cc10kD was performed on paraformal- 


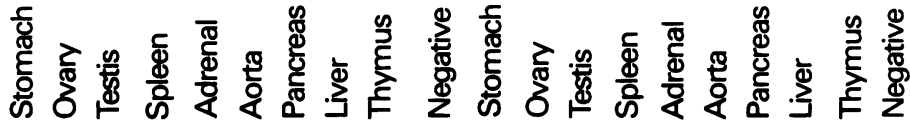

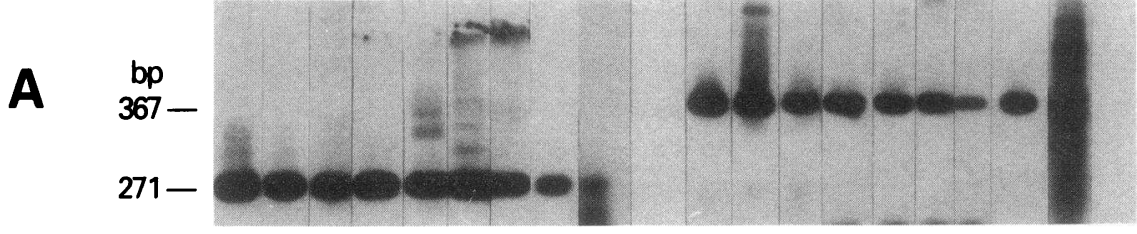

hULP-R/L

hUG -R/2

B

bp

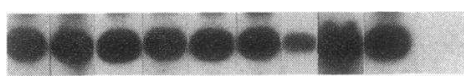

GAPDH - R/L

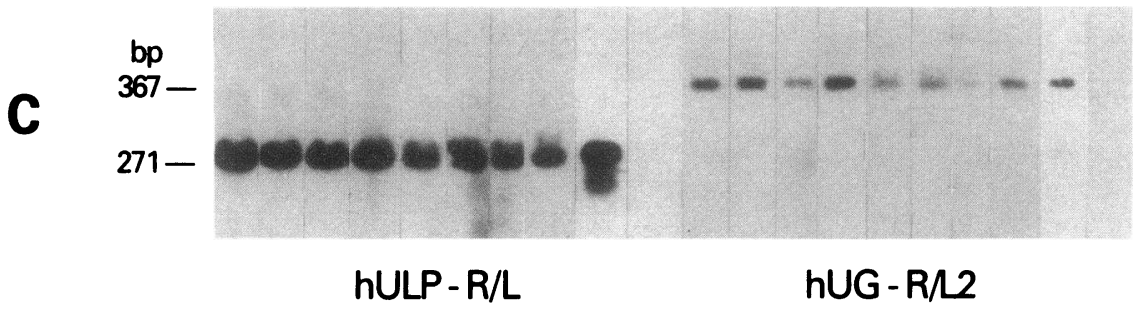

Figure 2. Chemilumigrams of PCR products obtained by amplifying various human cDNAs (top) using different sets of primers. ( $A$ ) hULP-R/L (left), hUG-R/L2 (right); (B) GAPDH-R/L; $(C)$ hULP-R/L (left), hUG-R/L2 (right) + hybridization with digoxigenin-labeled hUG-P. Negative, no cDNA control reaction. dehyde-fixed sections from human prostate, lung, thymus, and pituitary. Fig. 5 shows phase contrast pictures of the four tissues (Fig. 5, $A, C, E$, and $G$ ) and the corresponding cc10kD immunofluorescence (Fig. 5, $B, D, F$, and $H$ ). Bright immuno-

CTCCACCATGAAACTCGCTGTCACCCTCACCCTGGTCACACTGGCTCTCT CTCCACCATGAAAC -

GCTGCAGCTCCGCTTCTGCAGAGATCTGCCCGAGCTTTCAGCGTGTCATC 100 GCTGCAGCTCCGCTTCTGCAGAGATCTGCCCGAGCTTTCAGCGTGTCATC 57 - CTGCAGCTCCGCTTCTGCAGAGATCTGCCCGAGCTTTCAGCGTGTCATC 49 **********************************************

GAAACCCTCCTCATGGACACACCCTCCAGTTATGAGGCTGCCATGGAACT 150 GAAACCCTCCTCATGGACACACCCTCCAGTTATGAGGCTGCCATGGAACT 107 GAAACCCTCCTCATGGACACACCCTCCAGTTATGAG _......... 85

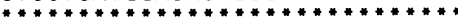

TTTCAGCCCTGATCAAGACATGAGGGAGGCAGGGGCTCAGCTGAAGAAGC 200 TTTCAGCCCTGATCAAGACATGAGGGAGGCAGGGGCTCAGCTGAAGAAGC 157 .

TGGTGGACACCCTCCCCCAAAAGCCCAGAGAAAGCATCATTAAGCTCATG 250

GAAAAAATAGCCCAAAGCTCACTGTGTAATTAGCATTTAGAAGCTGAAGA 300 GAAAAAATAGCCCAAAGCTCACT $\ldots \ldots$

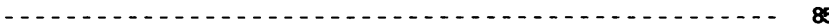

TCCCCAACTGCTCCAGCCTCTGCCGCTGCCATGCTTTGAGTCCACGCCCA 350 - 230

CCAGCCTTGCTCTCTTC 367

C................. 230

Figure 3. Partial nucleotide sequence of PCR products from human prostate and thymus cDNA, compared with the sequence of lung ccl0kD cDNA (3). hULP-R/L primers were used for PCR amplification. Top row, lung cc10kD cDNA; middle row, prostate PCR product; bottom row, thymus PCR product. fluorescence was detected in epithelial cells of the prostatic acini (Fig. $5 B$ ). In Fig. $5 D$ the bronchoalveolar epithelium of the lung is highly fluorescent, clearly suggesting the localization of cclokD in this tissue. In the case of the thymus (Fig. $5 F$ ) and the pituitary (Fig. $5 \mathrm{H}$ ), not all cells are fluorescent and the exact cell types showing cc10kD-specific fluorescence are more difficult to discern. The specificity of immunofluorescence of these tissues was confirmed by the fact that when the first antibody (rabbit anti-human cc10kD) was preadsorbed with pure recombinant cc10kD protein, no fluorescence was observed (not shown). In addition, omission of the first antibody also resulted in complete absence of immunofluorescence in these tissues (not shown).

\section{Discussion}

Our data indicate that cc10kD-specific transcripts are present in several nonrespiratory human organs and tissues. By using an antibody to rabbit UG, we have previously described a UGlike immunoreactivity in human endometrium (39), prostate (40), and respiratory tract (41).

In this study we combined the efficiency of the PCR amplification with the sensitivity of a detection method based on the chemiluminescent property of a dioxetane molecule (LumiPhos 530). Using two sets of specific sense and antisense primers derived from the sequence of the cDNA coding for cc10kD protein, we subjected human cDNAs from various organs to PCR amplification. Our data indicate that cc10kD-specific transcripts are present in high levels (signals detected in ethidium bromide-stained gels) in the following organs: lung, trachea, prostate, thyroid, mammary gland, and pituitary. A second group included tissues in which the signal could not be detected in ethidium bromide-stained gels, but intense specific signals were reproducibly found after immunochemiluminescent detection by Southern blotting. Stomach, ovary, testis, 


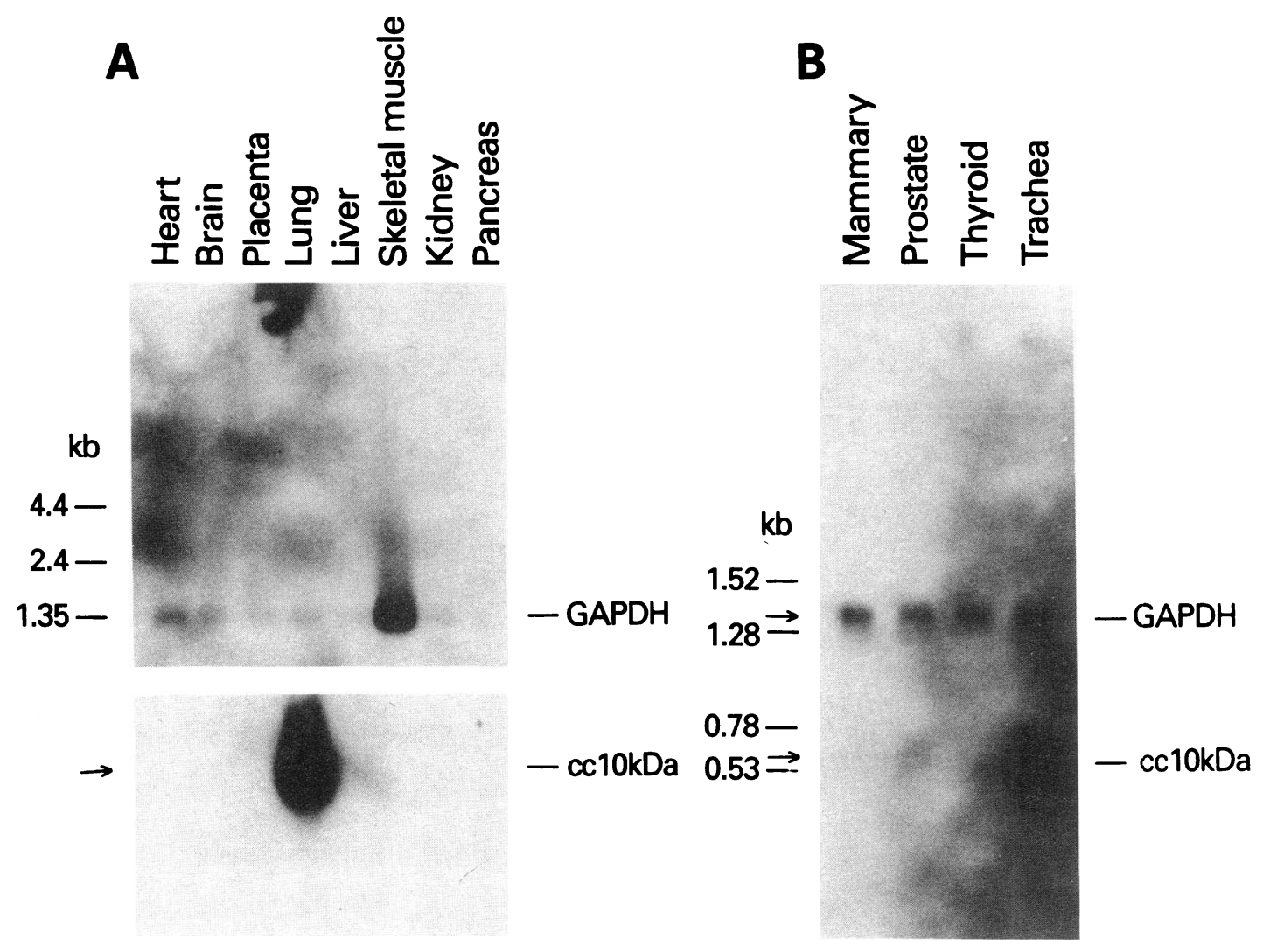

Figure 4. Northern blot: chemilumigrams showing ccl0kD $(0.6 \mathrm{~kb})$ and GAPDH ( $1.3 \mathrm{~kb}) \mathrm{mRNA}$-specific bands from multiple tissue Northern blot $(A)$ and from a Northern blot of human poly (A) ${ }^{+}$RNAs (see Methods) (B). (Top) Human organs or tissues.

spleen, adrenal, aorta, pancreas, liver, and thymus belong to this group. However, in the case of the pancreas, the densitometric analysis showed that the optical density ratio between cc10kD and GAPDH bands was 3.48. This indicates that the amount of cc10kD transcript in the pancreas may be higher than suggested by the absolute amount of PCR product. In a third group of tissues, undetectable or very weak signals were found by immunochemiluminescence. In some cases a specific product was detected only after prolonged exposure of the chemilumigram. This group included uterus, placenta, small intestine, heart, kidney, endothelium, brain, and leukocytes. Although for these tissues the possibility of "leaky transcription" (42) cannot be ruled out, detection of a low level of PCR product may also be because only a few cells in these organs contributed cc10kD mRNA. This is probably the case for the uterus

Table II. Densitometric Analysis of cclokD and GAPDH mRNA Bands in Fig. $4 B$

\begin{tabular}{lccc}
\hline \multicolumn{1}{c}{ Tissue } & $\begin{array}{c}\text { Area of } \\
\text { ccl0kD } \\
\text { band* }\end{array}$ & $\begin{array}{c}\text { Area of } \\
\text { GAPDH } \\
\text { band }\end{array}$ & $\begin{array}{c}\text { Ratio of } \\
\text { cc10kD } \\
\text { to GAPDH }\end{array}$ \\
\hline Trachea & 1.65 & 0.25 & 6.60 \\
Prostate & 0.10 & 0.21 & 0.48 \\
Mammary gland & 0.07 & 0.25 & 0.28 \\
\hline
\end{tabular}

* Areas were calculated by means of a reporting integrator (model 3390A; Pharmacia LKB Biotechnology) and are expressed in densitometric units $\times 10^{-7}$.
cDNA, which was derived from the whole organ rather than from endometrial epithelial cells, which are most likely to express cc $10 \mathrm{kD}$ gene. In a separate study, we noted that in human endometrial biopsies, both cc10kD mRNA and protein can be readily detected (Peri, A., B. D. Cowan, D. Bhartiya, L. Miele, L. K. Nieman, I. Nwaeze, and A. B. Mukherjee, manuscript submitted for publication). In rabbits the epithelial endometrial cells are by far the most important, if not the only, source of UG mRNA in the uterus (for a review see reference 9). Furthermore, the cc10kD gene, like the UG gene, may also be under ovarian steroid hormonal control. It is well known that, in the rabbit, a sharp increase in UG mRNA and uterine fluid UG occurs after estrogen-progesterone treatment $(43,44)$. It is possible that the uterus from which the CDNA was obtained was not in the appropriate stage of the ovarian menstrual cycle. Investigation of $\mathrm{cc} 10 \mathrm{kD}$ gene expression in the human endometrium at different phases of the ovarian cycle will be necessary to clarify the regulation of cc10kD expression in this tissue.

That the PCR products obtained in these experiments reflected cc $10 \mathrm{kD}$ transcription in various tissues was validated by the following criteria: $(a)$ two different sets of primers were used for each cDNA amplification, $(b)$ the products were recognized by a specific oligonucleotide probe corresponding to an internal sequence of $c c 10 \mathrm{kD}$ cDNA, and $(c)$ the PCR products from prostate (first group) and thymus (second group) were partially sequenced directly to avoid cloning artifacts that may have been caused by Taq polymerase. These sequences were identical to the published sequence of $\mathrm{cc} 10 \mathrm{kD} \mathrm{cDNA}$ from the lung (3). 

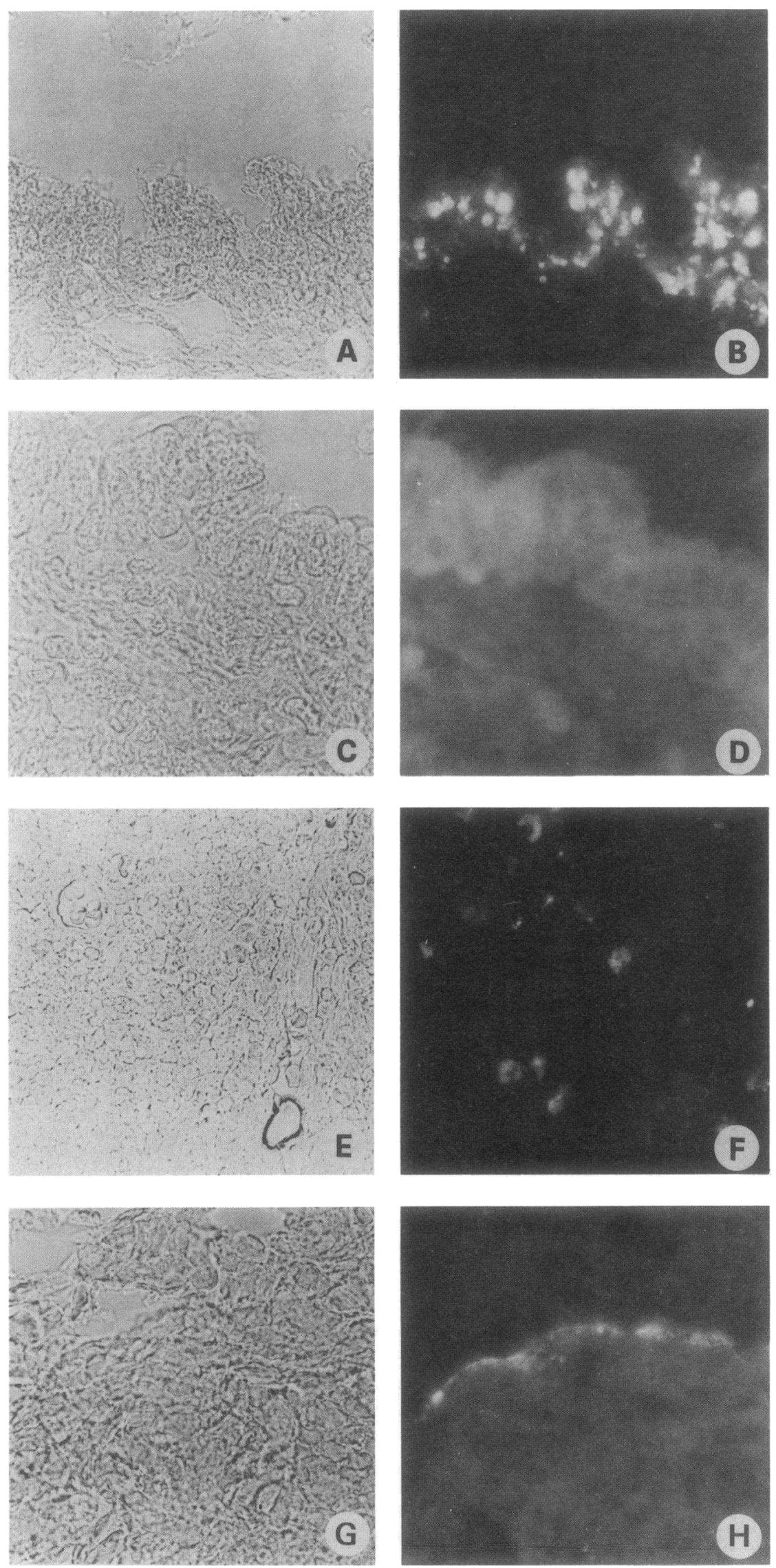

Figure 5. Indirect immunofluorescence on human tissue sections obtained with an antihuman cc10kD antibody. (Left) Phase contrast pictures of prostate $(A)$, lung $(C)$, thymus $(E)$, and pituitary $(G)$ are shown. (Right) The corresponding cc10kD immunofluorescence is shown ( $B$, prostate; $D$, lung; $F$, thymus; $H$, pituitary $(\times 630)$. 
It has been demonstrated that, at least in rats, the cc $10 \mathrm{kD}$ gene (45), like the UG gene $(46,47)$, is composed of three exons and two introns. In the human cclokD gene, the sequence analysis of the 5'-flanking region revealed a strong similarity with the rabbit UG gene at the first exon-intron boundary (4). In our study the primers for PCR analyses covered the entire coding region of cc $10 \mathrm{kD}$ cDNA. Therefore, any genomic DNA amplification would have included introns, resulting in a higher molecular mass PCR product than those actually obtained from amplification of cDNAs derived from various organs. Thus, we rule out the possibility that our results are artifacts due to genomic DNA contamination of the cDNAs used in our study.

Some of the tissues in which transcription of ccl0kD gene had been demonstrated by PCR were also tested by Northern blot analysis. Specific bands could be detected in the lung, trachea, prostate, and mammary gland under our experimental conditions. To our knowledge, this is the first time that mRNA for cc $10 \mathrm{kD}$ is detected in human organs other than the lung $(3$, 4 ) by Northern blotting. The relatively low sensitivity of this technique may explain the absence of specific bands for other organs, which were positive by PCR analysis. In rats, Northern blot analysis of total RNA extracted from various tissues revealed that, besides the lung, cc $10 \mathrm{kD}$ gene is transcribed in the esophagus and in the uterus of animals treated with estrogen and progesterone (45). However, no transcriptional activity was detected in the liver, heart, kidney, small intestine, brain, and parotid gland by this method (45).

Since only a particular cell type in an organ may produce cc $10 \mathrm{kD}$ mRNA, the results obtained from Northern analysis of RNAs prepared from whole organs cannot be used reliably to assess the abundance of transcript in specific cells. Detailed in situ hybridization studies will be necessary to establish which cell types express cc10kD in each organ. An additional caveat in quantitating the expression of $\mathrm{cc} 10 \mathrm{kD}$ is that the levels of protein synthesis are not necessarily proportional to the steadystate amount of mRNA. This has been observed for UG production in the rabbit endometrium $(43,44)$, in which after progesterone treatment, a disproportionately high level of protein was detected compared with the increase in mRNA level.

We also performed immunofluorescence studies in human lung, prostate, thymus, and pituitary using an antipeptide antibody against a specific epitope of human cc10kD. Our results indicate that $\mathrm{cc} 10 \mathrm{kD}$ protein is present in these four organs. In the prostate and in the lung, it is clear that cc $10 \mathrm{kD}$ protein is specifically expressed in the epithelial cells. These data are similar to those obtained for rabbit UG, which is produced mainly by epithelial cells (for a review see references 9,48 ). In addition, the cellular distribution of cc $10 \mathrm{kD}$ protein in human prostatic and respiratory epithelia is virtually identical to that previously observed with an antibody directed against rabbit UG, which cross-reacts with human cc10kD $(40,41)$.

It should be noted that our cc10kD antibody was raised against an oligopeptide derived from the $\alpha$-helix-3 of cc10kD protein. Crystallographic data (2) have revealed that in rat cc10kD this region of the molecule is exposed to the solvent and therefore, readily accessible for interaction with its antibody. Antibodies directed to other epitopes may not bind as avidly as our antibody. This could explain why an earlier study (1) did not detect cc10kD in organs other than the lung. Additional differences may also exist in the affinity of different
cc10kD antibodies, as well as in the preservation and fixation techniques.

All in all, our data indicate that although the respiratory epithelium is the major site of expression of the cc $10 \mathrm{kDa}$ gene in humans, the pattern of tissue distribution of cc10kD transcript is considerably more complex than previously realized. Our results suggest that the pattern of distribution of cclokD expression in human tissues is very similar, if not identical, to that of UG in the rabbit. In rabbits, immunological evidence of the presence of UG has been described in the ovary, oviduct, prostate, seminal vesicle, epididymis, vas deferens, lung, trachea, esophagus, mammary gland, small intestine, bladder, and thyroid (10-16). Fragments of the rabbit UG gene have been recently used to generate transgenic mice (49). Expression of the rabbit UG gene varied between strains and was dependent on the length of $5^{\prime}$ nontranscribed sequences included in the construct. In addition to the lung, UG gene was expressed, in at least some animals, in the ovary, uterus, testis, seminal vesicle, thymus, salivary gland, and kidney (49).

The possible physiological role $(\mathrm{s})$ of $\mathrm{cc} 10 \mathrm{kD}$ production in the organs identified by our study remains unknown. Several years ago we hypothesized that proteins of the UG family would be found in the epithelia of most mucosal organs communicating to the external environment (48). In view of the antiinflammatory and immunosuppressive properties of UG, it is tempting to speculate that local production of UG or ccl0kD by epithelial cells may be a mechanism directed to prevent undue activation of inflammatory processes that may cause tissue injury. Disregulated activation of inflammatory response in mucosal epithelia exposed to the external environment (e.g., airway epithelia) can result in unnecessary tissue damage in these organs. In addition, an inflammation-free environment is essential for the physiological function of other organs, such as the endocrine glands and especially the thymus, in which $T$ cell maturation occurs. The secretion of large amounts of cc $10 \mathrm{kD}$ in the airways, which are a major site of migration of leukocytes and exposure to extraneous agents, is consistent with this hypothesis. Moreover, the lung produces pancreatic type $\mathrm{PLA}_{2}$ (50), which is inhibited by $\operatorname{ccl} 10 \mathrm{kD}$ (5, $38 \mathrm{a})$. It is conceivable that cc10kDa may participate in protecting the airways from accidental activation of inflammatory processes, as well as from surfactant degradation by PLA $_{2}$. A similar role has been recently suggested for rabbit UG (51).

The presence of $\mathrm{cc} 10 \mathrm{kD}$ transcripts in numerous nonrespiratory organs also underscores the need for a detailed investigation of the regulation of $\mathrm{cc} 10 \mathrm{kD}$ gene expression. The use of the $5^{\prime}$ region of human ccl $10 \mathrm{kD}$ gene has been suggested in gene transfer experiments (4). This might elucidate the signifcance of cis-acting elements for the cell-specific expression of the human gene and might lead to the possible use of portions of its $5^{\prime}$ region in gene therapy for obtaining organ-specific expression of a wild-type gene in the respiratory epithelia. The 5 ' region of rat cc $10 \mathrm{kD}$ contains a cell-specific regulatory element located between positions -175 and +49 (52). This regulatory region confers lung-specific expression of a reporter gene in transgenic mice (52). Our present data suggest that the regulation of human cc10kD gene expression in vivo may be more complex, and that the high level of expression of this gene in the lung is accompanied by lower level of expression in multiple reproductive and nonreproductive tissues in vivo. It is possible that the relative abundance of cc10 kD mRNA in various 
organs may reflect the levels of specific transcription factors recognizing regulatory regions of its gene. This has been suggested to be the case for UG (49). A detailed analysis of the 5' region of the human gene will be necessary to establish whether respiratory epithelial cell-specific regulatory elements exist, and if so, what role these elements have in regulating the expression of this gene in vivo.

\section{Acknowledgments}

We thank Drs. H. Robinson, R. Dhanireddy, and M. Manyak for providing us with some of the autopsy specimens used for immunofluorescence.

\section{References}

1. Singh, G., J. Singh, S. L. Katyal, W. E. Brown, J. A. Kramps, I. L. Paradis, J. H. Dauber, T. A. Macpherson, and N. Squeglia. 1988. Identification, cellular localization, isolation, and characterization of human Clara cell-specific $10 \mathrm{KD}$ protein. J. Histochem. Cytochem. 36:73-80.

2. Umland, T. C., S. Swaminathan, W. Furey, G. Singh, J. Pletcher, and M. Sax. 1992. Refined structure of rat Clara cell $17 \mathrm{kDa}$ protein at $3.0 \AA \AA$ resolution. J. Mol. Biol. 224:441-448.

3. Singh, G., S. L. Katyal, W. E. Brown, S. Phillips, A. L. Kennedy, J. Anthony, and N. Squeglia. 1988. Amino-acid and cDNA nucleotide sequences of human Clara cell 10 kDa protein. Biochim. Biophys. Acta. 950:329-337.

4. Wolf, M., J. Klug, R. Hackenberg, M. Gessler, K. H. Grzeschik, M. Beato, and G. Suske. 1992. Human CC10, the homologue of rabbit uteroglobin: genomic cloning, chromosomal localization and expression in endometrial cell lines. Hum. Mol. Genet. 1:371-378.

5. Singh, G., S. L. Katyal, W. E. Brown, A. L. Kennedy, V. Singh, and M. L. Wong-Chong. 1990. Clara cell $10 \mathrm{kDa}$ protein (CC 10): comparison of structure and function to uteroglobin. Biochim. Biophys. Acta. 1039:348-355.

6. Nordlund-Moller, L., O. Andersson, R. Ahlgren, J. Schilling, M. Gillner, J. A. Gustafsson, and J. Lund. 1990. Cloning, structure, and expression of a rat binding protein for polychlorinated biphenyls. J. Biol. Chem. 265:12690-12693.

7. Krishnan, R. S., and J. C. Daniel, Jr. 1967. Blastokinin: inducer and regulator of blastocyst development in the rabbit uterus. Science (Wash. DC). 158:490492.

8. Beier, H. M. 1968. Uteroglobin: a hormone sensitive endometrial protein involved in blastocyst development. Biochim. Biophys. Acta. 160:289-291.

9. Miele, L., E. Cordella-Miele, and A. B. Mukherjee. 1987. Uteroglobin: structure, molecular biology, and new perspectives on its function as a phospholipase $\mathrm{A}_{2}$ inhibitor. Endocr. Rev. 8:474-490.

10. Kay, E., and M. Feigelson. 1974. An estrogen modulated protein in rabbit oviductal fluid. Biochim. Biophys. Acta. 271:436-441.

11. Beier, H. M., H. Bohn, and W. Muller. 1975. Uteroglobin-like antigen in the male genital tract secretion. Cell Tissue Res. 165:1-11.

12. Kirchner, C. 1976. Uteroglobin in the rabbit: intracellular localization in the oviduct, uterus and pre-implantation blastocyst. Cell Tissue Res. 170:425434.

13. Kirchner, C., and H. G. Schroer. 1976. Uterine secretion-like proteins in the seminal plasma of the rabbit. J. Reprod. Fertil. 47:325-330.

14. Noske, I. G., and M. Feigelson. 1976. Immunological evidence of uteroglobin (blastokinin) in the male reproductive tract and in non reproductive ductal tissues and their secretions. Biol. Reprod. 15:704-713.

15. Noske, I. G., and M. Gooding. 1978. Evidence of a uteroglobin-like protein in epithelial cells of reproductive and non-reproductive tissues of the rabbit. Reprod. Fert. 54:193-196.

16. Daniel, J. C., Jr., and J. T. Milazzo. 1976. Continuity of a rabbit antigen between generations. Cancer Res. 36:3409-3411.

17. Mukherjee, A. B., K. Laki, and A. K. Agrawal. 1980. Possible mechanism of success of an allotransplantation in nature: mammalian pregnancy. $\mathrm{Med}$. $\mathrm{Hy}$ potheses. 6:1043-1055.

18. Mukherjee, A. B., R. E. Ulane, and A. K. Agrawal. 1982. Role of uteroglobin and transglutaminase in masking the antigenicity of implanting rabbit embryos. Am. J. Reprod. Immunol. 2:135-141.

19. Mukherjee, A. B., D. Cunningham, A. K. Agrawal, and R. Manjunath. 1982. Role of uteroglobin and transglutaminase in self and nonself recognition during reproduction in the rabbit. Ann. NY Acad. Sci. 392:401-402.

20. Mukherjee, D. C., R. E. Ulane, R. Manjunath, and A. B. Mukherjee. 1983. Suppression of epididymal sperm antigenicity in the rabbit by uteroglobin and transglutaminase in vitro. Science (Wash. DC). 219:989-991.

21. Schiffman, E., V. Geetha, D. Pencev, H. Warabi, J. Mato, F. Hirata, M.
Brownstein, R. Manjunath, A. B. Mukherjee, L. Liotta, et al. 1983. Adherence and regulation of leukotaxis. Agents Actions Suppl. 12:106-120.

22. Schiffman, E., V. Geetha, D. Pencev, J. Mato, I. Garcia-Castro, P. K. Chiang, R. Manjunath, and A. B. Mukherjee. 1984. Phospholipid metabolism and regulation of leukocyte chemotaxis. Proc. Asthma: Physiol., Immunopharmacol. Treatment, 3rd Int. Symp. 173-193.

23. Vasanthakumar, G., R. Manjunath, A. B. Mukherjee, H. Warabi, and E. Schiffman. 1988. Inhibition of phagocyte chemotaxis uteroglobin, an inhibitor of blastocyst rejection. Biochem. Pharmacol. 37:389-394.

24. Manjunath, R., S. W. Levin, K. K. Kumaroo, J. D. Butler, J. Donlon, H. McDonald, R. Fujita, U. K. Schumacher, and A. B. Mukherjee. 1987. Inhibition of thrombin-induced platelet aggregation by uteroglobin. Biochem. Pharmacol. 36:741-746.

25. Levin, S. W., J. D. Butler, U. K. Schumacher, P. D. Wightman, and A. B. Mukherjee. 1986. Uteroglobin inhibits phospholipase $A_{2}$ activity. Life Sci. 38:1813-1819.

26. Miele, L., E. Cordella-Miele, A. Facchiano, and A. B. Mukherjee. 1988. Novel anti-inflammatory peptides from the region of highest similarity between uteroglobin and lipocortin I. Nature (Lond.). 335:726-730.

27. Tetta, C., G. Camussi, F. Bussolino, K. Heriick-Davis, and C. Baglioni. 1991. Inhibition of the synthesis of platelet-activating factor by antiinflammatory peptides (antiflammins) without methionine. J. Pharmacol. Exp. Ther. 257:616-620.

28. Perretti, M., C. Becherucci, G. Mugridge, E. Soliteo, S. Silvestri, and L. Parente. 1991. A novel antiinflammatory peptide from lipocortin V. Br. J. Pharmacol. 103:1327-1332.

29. Miele, L., E. Cordella-Miele, A. Facchiano, and A. B. Mukherjee. 1990. Inhibition of phospholipase $\mathrm{A}_{2}$ by uteroglobin and antiflammin peptides. $A d v$. Exp. Med. Biol. 279:137-160.

30. Camussi, G., C. Tetta, F. Bussolino, and C. Baglioni. 1990a. Antiinflammatory peptides (antiflammins) inhibit synthesis of platelet-activating factor, neutrophil aggregation and chemotaxis, and intradermal inflammatory reactions. J. Exp. Med. 171:913-927.

31. Camussi, G., C. Tetta, and C. Baglioni. 1990b. Antiflammins inhibit synthesis of platelet-activating factor and intradermal inflammatory reactions. Adv. Exp. Med. Biol. 279:161-172.

32. Ialenti, A., P. M. Doyle, G. N. Hardy, D. S. Simpkin, and M. Di Rosa. 1990. Anti-inflammatory effects of vasocortin and nonapeptide fragments of uteroglobin and lipocortin I (antiflammins). Agents Actions. 1-2:48-49.

33. Di Rosa, M., and A. Ialenti. 1990. Selective inhibition of inflammatory reactions by vasocortin and antiflammin 2. In Cytokines and Lipocortin in Inflammation and Differentiation. M. Melli and L. Parente, editors. Plenum Press, New York. 81-90.

34. Chan, C. C., M. Ni, L. Miele, E. Cordella-Miele, A. B. Mukherjee, and R. B. Nussenblatt. 1990. Antiflammins: inhibition of endotoxin-induced uveitis in Lewis rats. In Ocular Immunology Today. M. Usui, S. Ohno, and K. Aoki, editors. Elsevier Science, Tokyo. 467-470.

35. Chan, C. C., M. Ni, L. Miele, E. Cordella-Miele, M. Ferrick, A. B. Mukherjee, and R. B. Nussenblatt. 1991. Effects of antiflammins on endotoxin-induced uveitis in rats. Arch. Ophthalmol. 109:278-281.

36. Cabré, F., J. J. Moreno, A. Carabaza, E. Ortega, D. Mouleon, and G. Carganico. 1992. Antiflammins: anti-inflammatory activity and effect on human phospholipase $\mathrm{A}_{2}$. Biochem. Pharmacol. 44:519-525.

37. Lloret, S., and J. J. Moreno. 1992. In vitro and in vivo effects of the anti-inflammatory peptides, antiflammins. Biochem. Pharmacol. 44:1437-1441.

38. Dveksler, G. S., A. A. Basile, and C. W. Dieffenbach. 1992. Analysis of gene expression: use of oligonucleotide primers for glyceraldhehyde-3-phosphate dehydrogenase. PCR Methods Appl. 1:283-285.

38a.Mantile, C., L. Miele, E. Cordella-Miele, G. Singh, S. Katyal, and A. B. Mukherjee. 1993 The human Clara cell lokDa protein is the counterpart of rabbit uteroglobin. J. Biol. Chem. In press.

39. Kikukawa, T., B. D. Cowan, R. I. Tejada, and A. B. Mukherjee. 1988. Detection of a rabbit uteroglobin-like protein in the human endometrium. $J$. Clin. Endocrinol. Metab. 67:315-321.

40. Manyak, M. J., T. Kikukawa, and A. B. Mukherjee. 1988. Expression of a uteroglobin-like protein in human prostate. J. Urol. 140:176-182.

41. Dhanireddy, R., T. Kikukawa, and A. B. Mukherjee. 1988. Detection of a rabbit uteroglobin-like protein in human neonatal tracheobronchial washings. Biochem. Biophys. Res. Commun. 152:1447-1454.

42. Bloch, W. 1991 A biochemical perspective of the polymerase chain reaction. Biochemistry. 30:2735-2747.

43. Janne, O., S. Hemminki, V. V. Isomaa, H. Isotalo, H. Kopu, M. Orava, and T. Torkkeli. 1980. Uteroglobin synthesis and its relationship to changes in progesterone receptors, RNA polymerase and poly-A polymerases in the rabbit uterus. Dev. Endocrinol. 8:319-340.

44. Janne, O., V. V. Isomaa, T. K. Torkkeli, H. E. Isotalo, and H. T. Kopu. 1983. Hormonal regulation of uteroglobin synthesis in the rabbit uterus. In Progesterone and Progestins. C. Wayne Bardin, E. Milgrom, and P. Mauvais-Jarvis, editors. Raven Press, New York. 33-47. 
45. Hagen, G., M. Wolf, S. L. Katyal, G. Singh, M. Beato, and G. Suske. 1990. Tissue-specific expression, hormonal regulation and 5'-flanking gene of the rat Clara cell $10 \mathrm{kDa}$ protein: comparison to rabbit uteroglobin. Nucleic Acids Res. 18:2939-2946.

46. Bailly, A., M. Atger, P. Atger, M. A. Cerbon, M. Alison, M. T. V. Hai, F. Logeat, and E. Milgrom. 1983. The rabbit uteroglobin gene: structure and interaction with the progesterone receptor. J. Biol. Chem. 258:10384-10389.

47. Suske, G., M. Wenz, A. C. B. Cato, and M. Beato. 1983. The uteroglobin gene region: hormonal regulation, repetitive elements and complete nucleotide sequence. Nucleic Acids Res. 11:2257-2271.

48. Mukherjee, A. B., E. Cordella-Miele, T. Kikukawa, and L. Miele. 1988. Modulation of cellular response to antigens by uteroglobin and transglutaminase. Adv. Exp. Med. Biol. 231:135-152.
49. DeMayo, F. J., S. Damak, T. N. Hansen, and D. Bullock. 1991. Expression and regulation of the rabbit uteroglobin gene in transgenic mice. Mol. Endocrinol. 5:311-318.

50. Seilhamer, J., T. L. Randall, M. Yamanaka, and L. K. Johnson. 1986. Pancreatic phospholipase $A_{2}$ : isolation of the human gene and cDNA from porcine pancreas and human lung. DNA. 5:519-527.

51. Guy, J., R. Dhanireddy, and A. B. Mukherjee. 1992. Surfactant-producing pulmonary alveolar type II cells synthesize and secrete an antiinflammatory protein, uteroglobin. Biochem. Biophys. Res. Commun. 189:662-669.

52. Stripp, B., P. L. Sawaya, D. S. Luse, K. A. Wikenheiser, S. E. Wert, J. A Huffman, D. L. Lattier, G. Singh, S. L. Katyal, and J. A. Whitsett. 1992. cis-Acting elements that confer lung epithelial cell expression of the $\mathrm{CC}_{10}$ gene. J. Biol. Chem. 267:14703-14712. 